\title{
EFEKTIFITAS TERAPI AKUPUNKTUR DIKOMBINASI DENGAN DIET BERSERAT TINGGI PADA USIA LANJUT HIPERLIPIDEMIA DI POSYANDU LANSIA MOJOSONGO, JEBRES KOTA SURAKARTA
}

\author{
Sumanto, Maria Dewi Kristiyawati \\ Poltekkes Kemenkes Surakarta Jurusan Akupuntur
}

\begin{abstract}
Background: The purpose of this study was to study a combination of high-fiber combination diet acupuncture therapy to increase cholesterol in hyperlipidemic women at the Posyandu elderly Mojosongo Village, Jebres Surakarta City. Method: Quasi experimental with one Grous research design pretest - post test design. The focus of the study was the use of a combination of high fiber diet acupuncture therapy to improve blood cholesterol in hyperlipidemic women. Acupuncture therapy is carried out by acupuncture health therapists who have an official permit or license from a supported body. Data retrieval is done by interview / history and observation and fill out the questionnaire after getting acupuncture therapy. Data analysis will use t-test for prejustification of data and acupuncture therapy post, then processed with SPSS series 16.0 program. Result: Acupuncture in combination with high fiber diet can reduce total cholesterol and triglycerides. Ling Li further explained that the effect of electroacupuncture stimulation on the ST40 point could induce the expression of nNOS and Mt1 enzymes. The NNOS enzyme mediates nitric oxide (NO) signals and plays an important role in cellular signals, vascular tone, blood pressure, insulin hormone secretion, respiratory tract tone, angiogenesis and intestinal peristalsis. Mt1 plays an important role in protecting cells against the body's oxidative attacks, therefore electroacupuncture is effective in reducing cholesterol and triglycerides. Conclusion: A combination of high fibrous diet in improving blood cholesterol in hyperlipidemic women at the posyandu lansia kelurahan Mojosongo, jebres, Surkarta City
\end{abstract}

Keywords: Blood clamps, total cholesterol, HDL cholesterol, LDL cholesterol, triglycerides, combination of high fiber diet combination acupuncture.

\section{PENDAHULUAN}

Hiperlipidemia

dalam

penjelasannya diterangkan bahwa nilai kadar lemak, yaitu kolesterol maupun trigliserida serum darah di atas normal (Sylvia \& Wilson, 2005). Secara klinis hiperlipidemia ditandai oleh nilai kolesterol total dan low density lipoprotein (LDL) serum darah meningkat di atas normal, sedangkan nilai kolesterol high density lipoprotein (HDL) serum darah menurun di bawah normal Nilai kadar kolesterol tottal normal yaitu $<200$ mg/dl; nilai kadar kolesterol LDL normal yaitu $<100 \mathrm{mg} / \mathrm{dl}$; nilai kadar trigliserida yaitu $<150 \mathrm{mg} / \mathrm{dl}$ dan nilai kolesterol HDL > $40-60 \mathrm{mg} / \mathrm{dl}$ (Sukandar, dkk, 2008).

Hipertrigliserida diperankan oleh hormone sensitive lipase (HSL) dalam mengendalikan dan menggerakkan kolesterol darah. Hipertrigliseridemia terutama pada diabetes mellitus tipe 1 dikaitkan dengan peningkatan serum very 
low density lipoprotein (VLDL). Peningkatan VLDL disebabkan oleh beberapa factor, diantaranya: meningkatnya aktifitas hormone sensitive lipase (HSL) dan menurunnya degradasi apolipoprotein B100 (Richards S et al, 2015).

Terapi medis pada hiperlipidemia bertujuan untuk menurunkan kadar kolesterol total, menurunkan LDL dan meningkatkan HDL. Adapun Obat-obat antihiperlipidemia dapat dikelompokkan menjadi lima macam yaitu obat golongan inhibitor HMG KoA reduktase (statin), obat golongan resin pertukaran anion, asam nikotinat, fibrat, dan inhibitor pada absorpsi kolesterol usus (Neal, 2005). Efek samping obat anti hiperlipidemia, misalnya: golongan statin diantaranya: mengganggu pertumbuhan janin, menimbulkan sakit lambung, gangguan otot, mengganggu fungsi ginjal, sakit kepala dan insomnia (Albert Okorocha. 2015).

Penatalaksanaan terapi pada pasien dengan hiperlipidemia atau dyslipidemia dapat memilih salah satu alternative dan atau komplementer terapi pada kasus hiperlipidemia atau dislipidemia, misalnya: terapi akupunktur. Akupunktur secara tradisional merupakan upaya memperlancar hambatan energy (Qi) dan mengembalikan kelancaran sirkulasi energy melalui saluran meridian tubuh. Secara saintifikasi akupunktur bekerja dengan merangsang system penyembuhan alami tubuh (Wei He, \& Bing Zhu. 2015).

Berdasar pada penelitian keilmuan telah ditemukan ada 3 (tiga) mekanisme kerja akupunktur yaitu: neurologi, biokimia dan biolistrik. Penelitian telah dilakukan sejak tahun 1980-an dijelaskan bahwa: akupunktur bekerja dengan merangsang pelepasan endorphin, keseimbangan cairan, elektrolit dan asam basa) kimia tubuh dan meningkatkan kelancaran peredaran darah serta perbaikan jaringan tubuh. Akupunktur mulai bekerja dari tempat penusukan jarum (lesi mikro) meneruskan signal saraf ke otak yang mengatur persepsi nyeri dan meningkatkan kinerja system saraf autonom untuk mengatur fungsi autonomi seperti kerja jantung, respirasi dan digesti. Akupunktur dapat meningkatkan aliran darah, karena tubuh memerlukan kesembuhan cidera dengan kecukupan darah, oksigen, nutrisi, zat immunitas, hormone, analgetik (pereda sakit) dan antiinflamasi. Perbaikan sirkulasi darah adalah penting untuk meningkatkan dan memelihara kesehatan tubuh. Efek terhadap neurotransmitter yaitu: stabilitas kadar Seratonin and noradrenaline baik di saraf pusat dan perifer selama terapi akupunktur dapat melancarkan pernafasan, menenangkan kecemasan dan relaksasi tubuh serta mempermudah tidur (Tieraona Low Dog. 2003.

Berdasar uraian tersebut diatas, kami akan meneliti dengan judul pengaruh akupunktur yaitu titik LI11 (Quchi), CV12 (Zhongwan) and ST40 (fenglong) terhadap penurunan hiperlipidemia/ dislipidemia lansia di Posyandu Lansia di Kota Surakarta.

Tujuan penelitian ini adalah untuk mendiskripsikan pengaruh terapi akupunktur kombinasi diet berserat tinggi terhadap penurunan kadar lemak darah (LDL, Trigliserida, HDL) pada wanita hiperlipidemia di Posyandu lansia Mojosongo.

\section{METODE PENELITIAN}


Metoda penelitian ini adalah Quasi Eksperimental dengan one group pre dan post test pada wanita lanjut usia di Posyandu Lansia Mojosongo. Variable penelitian ini adalah Variabel bebas yaitu Tindakan Akupunktur kombinasi makanan berserat tinggi dan Variabel terikat yaitu Perbaikan nilai kolesterol darah: kolesterol total, kolesterol LDL, kolesterol HDL, dan Trigliserida puasa pada wanita Pra lansia dan lansia di posyandu Kelurahan Mojosongo, Jebres, Kota Surakarta.

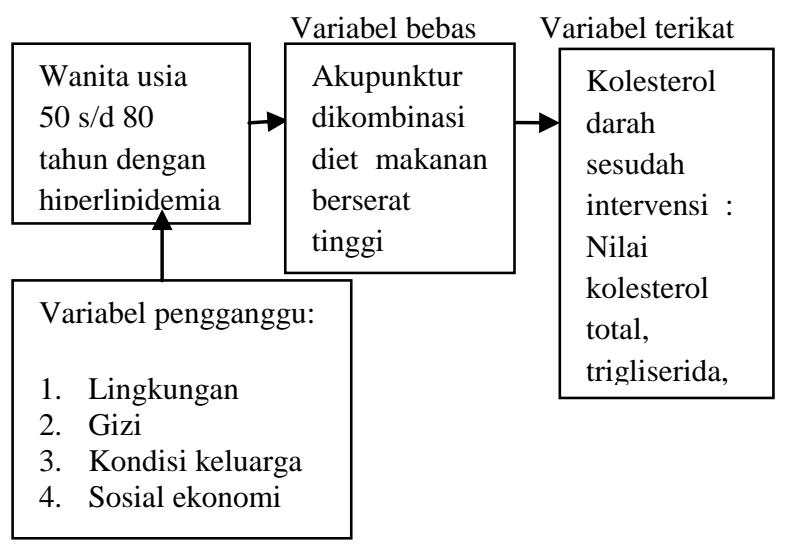

Skema 1. Kerangka Konsep Penelitian

\section{HASIL PENELITIAN}

\section{a. Nilai rerata lemak darah pea dan} paska akupunktur

Nilai kolesterol total, Trigliserida, Kolesterol LDL dan Kolesterol HDL antara sebelum dan sesudah menjalani akupunktur (9 kali) kombinasi diet berserat tinggi.

Tabel 1. Nilai rerata lemak darah pea dan paska akupunktur

\begin{tabular}{|c|c|c|c|c|c|}
\hline Variabel & \multirow{2}{*}{$\begin{array}{c}\text { Nilai } \\
\text { dependen }\end{array}$} & \multicolumn{2}{|c|}{ Sebelum } & \multicolumn{2}{|c|}{ Sesudah } \\
\cline { 3 - 6 } & Kolesterol & Frek & $(\%)$ & Frek & $(\%)$ \\
\hline $\begin{array}{c}\text { Kolesterol } \\
\text { total }\end{array}$ & $\mathrm{X}<200$ & 6 & 24 & 17 & 68 \\
\hline & $\begin{array}{c}200<\mathrm{x} \\
>239\end{array}$ & 14 & 56 & 4 & 16 \\
\hline
\end{tabular}

\begin{tabular}{|c|c|c|c|c|c|}
\hline & $\mathrm{X}>240$ & 5 & 20 & 4 & 16 \\
\hline & Jumlah & 25 & 100 & 25 & 100 \\
\hline Trigliserida & $\mathrm{X}<130$ & 9 & 36 & 16 & 64 \\
\hline & $\begin{array}{c}131<\mathrm{x} \\
>159\end{array}$ & 8 & 32 & 2 & 8 \\
\hline & $\mathrm{X}>160$ & 8 & 32 & 7 & 28 \\
\hline & Jumlah & 25 & 100 & 25 & 100 \\
\hline $\begin{array}{c}\text { Kolesterol } \\
\text { HDL }\end{array}$ & $\mathrm{X}<35$ & 21 & 84 & 20 & 80 \\
\hline & $\begin{array}{c}35<\mathrm{X}> \\
45\end{array}$ & 3 & 12 & 5 & 20 \\
\hline & $\mathrm{X}>45$ & 1 & 4 & 0 & 0 \\
\hline & Jumlah & 25 & 100 & 25 & 100 \\
\hline $\begin{array}{c}\text { Kolesterol } \\
\text { LDL }\end{array}$ & $\mathrm{X}<150$ & 15 & 60 & 21 & 84 \\
\hline & $\begin{array}{c}151<\mathrm{x} \\
>500\end{array}$ & 10 & 40 & 4 & 16 \\
\hline & $\mathrm{X}>500$ & 0 & 0 & 0 & 0 \\
\hline & Jumlah & 25 & 100 & 25 & 100 \\
\hline
\end{tabular}

Sumber: SPSS serie 16.0

\section{b. Analisis Bivariat}

1. Kolesterol: Nilai kadar kolesterol total sebelum dan setelah dilakukan Akupunktur dikombinasi makanan berserat tinggi di Posyandu Lansia Kelurahan Mojosongo, Jebres tahun 2018 (N. 25), menunjukkan bahwa mean kolesterol sebelum terapi akupunktur kombinasi makan berserat tinggi sebesar 216.84, jumlah sampel 25, standar deviasi 48.712, mean standar error 9.742. Mean kolesterol sesudah terapi akupunktur kombinasi makan berserat tinggi sebesar 184.72, jumlah sampel 25, standar deviasi 42.657, mean standar error 8.531. Hasil nilai t-tes Kolesterol sebelum dan sesudah dilakukan Akupunktur kombinasi diet berserat tinggi bahwa mean sebesar 32.120, convidance interval 95\%: nilai terendah 19.664, dan nilai tertinggi 44.576, maka nilai t-tes hitung sebesar 5.322, pada df. 24, dengan signifikansi 2 tail nilai t-tabel adalah 2.06390 sebesar 0.000 . 
2. Trigliserida: Nilai kadar Trigliserida sebelum dan setelah dilakukan Akupunktur dikombinasi diet berserat tinggi di Posyandu Lansia Mojosongo tahun 2018 (N. 25). Hasil nilai t-tes Trigliserida sebelum dan sesudah dilakukan Akupunktur dikombinasi diet berserat tinggi bahwa mean sebesar 45.920, convidance interval 95\%: nilai terendah 19.664, dan nilai tertinggi 44.576, maka nilai t-tes hitung adalah 5.322, pada df. 24, dengan signifikansi 2 tail, dan nilai t-tabel adalah 2.06390, (0.000).

3. LDL: Nilai kadar Low density lipid (LDL) sebelum dan setelah dilakukan Akupunktur dikombinasi diet berserat tinggi di Posyandu Lansia Mojosongo, Jebres tahun 2018 (N. 25). Hasil nilai t-tes Trigliserida sebelum dan sesudah dilakukan Akupunktur kombinasi diet berserat tinggi bahwa mean sebesar 22.600, convidance interval 95\%: nilai terendah 12.198, dan nilai tertinggi 33.002 , maka nilai t-tes hitung adalah 4.484 , pada df. 24 , dengan signifikansi 2 tail, nilai t-tabel adalah 2.06390 (0.000).

4. HDL (high density lipide): Nilai kadar HDL sebelum dan setelah dilakukan Akupunktur dikombinasi diet berserat tinggi di Posyandu Lansia Mojosongo tahun 2018 (N. 25). Hasil nilai t-tes HDL sebelum dan sesudah dilakukan Akupunktur kombinasi diet berserat tinggi bahwa mean sebesar 0.080 convidance interval 95\%: nilai terendah -1.577 , dan nilai tertinggi 1.417 ; maka nilai t-tes hitung sebesar -110 , pada df. 24 degnan signifikansi 2 tail, nilai ttabel adalah $2.06390(0.913)$.

\section{PEMBAHASAN}

Pembahasan dalam penelitian ini menjelaskan tentang hasil penelitian dan membandingkan hasil penelitian ini dengan penelitian sebelumnya yang serupa dan teori - teori yang mendukung atau berlawanan dengan temuan baru. Permbahasan pertama tentang karakteristik responden meliputi usia, dan komponen lemak darah. Pada bagian berikutnya akan dibahas tentang hasil uji analisis uji beda rerata untuk masing masing variabel. Pada bagian terakhir bab ini akan dibahas tentang keterbatasan penelitian, implikasi dan tindak lanjut hasil penelitian yang dapat diterapkan dan diaplikasikan pada pelayanan kesehatan $\mathrm{d}$ Adapun komponen lemak darah puasa tersebut meliputi : nilai kolesterol total, kolesterol HDL, kolesterol LDL dan Trigliserida. Perbaikan komponen lemak darah puasa tersebut di dapatkan karena adanya stimulasi secara berkala berupa tindakan akupunktur kombinasi diet makanan berserat tinggi.

Pada umumnya problema akupunktur hiperlipidemia yaitu: flegma lembab, stasis sirkulasi darah jaringan, dan defisiensi-insufisiensi lambung dan limpa, serta defisiensi ginjal dan liver. Tindakan akupunktur untuk memperbaiki kolesterol terutama memfokuskan pada tercapainya kondisi keseimbangan fungsional sistem tubuh. Pada kondisi tubuh yang mengalami flegma lembab, maka tujuan terapinya adalah membantu tubuh mentransformasi patogen, melalui titik akupunktur yaitu ST40, dan SP9. Untuk memperlancar stasis sirkulasi darah jaringan menggunakan titik akupunktur SP10, Li4 dan Liv3. Untuk meningkatkan fungsional lambung dan limpa dapat ditambahkan titik akupunktur ST36 dan SP6. Untuk meningkatkan fungsional ginjal dan liver didukung oleh 
titik akupunktur Liv3, Ki3, B123 dan B118 (Anonima).

Sebagaimana disampaikan oleh Zhang et.all, bahwa akupunktur dengan elektrostimulator dapat dapat menurunkan lemak darah terutama kolesterol dan trigliserida terutama titik Li11, CV12, dan ST40 efektif dapat menurunkan kolesterol LDL, kolesterol total dan trigliserida. Menurut Ling $\mathrm{Li}$, et.al. bahwa akupunktur titik ST40 dapat menurunkan kolesterol total dan trigliserida. Lebih lanjut Ling $\mathrm{Li}$ menjelaskan efek rangsang elektroakupunktur pada titik ST40 dapat menginduksi ekspresi enzim nNOS dan Mt1. Enzim NNOS memediasi signal nitric oksida (NO) dan memainkan peran penting dalam signal seluler, tonus vaskuler, tekanan darah, sekresi hormon insulin, tonus saluran respirasi, angiogenesis dan peristaltik usus. Mt1 berperan penting untuk memproteksi sel terhadap serangan stres oksidatif tubuh, karena itu elektroakupunktur efektif menurunkan kolesterol dn trigliserida. Selanjutnya YF Chen et.al, menjelaskan bahwa akupunktur dapat mencegah bahaya akumulasi lemak seluler pada kasus hiperkolesterolemia. Pada penelitiannya di laboratorium dijelaskan bahwa akupunktur titik ST40 dapat mencegah dn mengurai pembentukan foam sel pada pembuluh darah. Foam sel ini dapat berkembang menjadi pemicu aterosklerosis. Bentukan foam sel ini mengindikasikan adanya resiko penyakit serangan jantung dan penyumbatan pembuluh darah otak (stroke). Perkembangan oksidasi kolesterol lebih lanjut dijelaskan bahwa oksidasi kolesterol LDL akan berkembang menjadi inflamasi pembuluh darah. Makrofag ditarik ke tempat pembuluh yang mengalami inflamasi dan mengonsumsi kolesterol LDL. Makrofag bertahan melawan bakteri patogen pada pembuluh inflamasi, namun makrofag mengalami kesulitan berthan akibat terjerat oleh akumulasi kolesterol, sehingga terbentuk foam sel pada pembuluh darah tersebut. Karenanya bentukan foam sel pada pembuluh darah menandai resiko serangan penyakit jantung. Titik akupunktur ST40 dilaporkan efektif mencegah bentukan foam sel dan mengurai akumulasi kolesterol pada pembuluh darah, sehingga dapat mencegah serangan penyakit jantung.

Meskipun banyak titik berbeda yang digunakan untuk tindakan akupunktur, namun titik akupunktur tersebut berkaitan dengan fungsi bagian tubuh tertentu, dan jalur syaraf merupakan struktur fisik yang mempermudah akupunktur mencapai targetnya. Ujung syaraf diseluruh tubuh dihubungkan melalui spinal cord (tali antara kedua titik) dalam sumsum belakang pada bidang - bidang tertentu dari otak dengan system cara dari jalur syaraf. Terdapat teori mulai dari fungsi fisik system syaraf pada waktu distimulas melalui titik - titik akupuntur tertentu mendorong batang otak, cerebral cortex, hypothalamus dan akhirnya kelenjar hipotalamus-hipofisis mengendalikan secara kimiawi melalui neurotransmitter dan hormone meningkatkan metabolisme lemak sel, sirkulasi darah, lebih banyak mengirimkan oksigen, sehingga menstimulasi dan menutrisi jaringan otak dengan baik dan mampu merangsang pusat otak berhubungan dengan metabilisme sel meliputi: kolesterol total, LDL, HDL dan trigliserida. Titik akupunktur yang digunakan untuk 
menstimulasi metabolisme lemak darah antara lain Titik tersebut yaitu: GV20, ST40, ST11, ST12, TH16, TH17. Titik Baihui (GV 20) memiliki manfaat untuk melancarkan sirkulasi Qi dan darah ke jaringan otak sehingga membantu otak mendapatkan nutrisi yang adekuat. Titik akupunktur St40 untuk mengatasi keadaan flegma lembab dingin, titik akupunktur Sp10, dan titik akupunktur Sj6 untuk mengatasi flegma lembab panas disertai keluhan konstipasi. Sedangkan titik akupunktur Auricular titik Pancreas, Liver, Small Intestine, Prostate dapat memperbaiki metabolisme lemak. (Kayne, 2010, Diane Joswick, 2012).

\section{KESIMPULAN DAN SARAN}

Kadar lemak darah tinggi (hiperlipidemi) berkaitan dengan Liver $\mathrm{X}$ receptors (LXRs). LXRs adalah faktor transkripsi reseptor nuklear yang berperan penting dalam mengatur keseimbangan antara cholesterol, triglyceride, fatty acid, dan glucose.

Akupunktur dikombinasi diet berserat tinggi dapat menurunkan kolesterol total dan trigliserida. Lebih lanjut Ling Li menjelaskan efek rangsang elektroakupunktur pada titik ST40 dapat menginduksi ekspresi enzim nNOS dan Mt1. Enzim NNOS memediasi signal nitric oksida (NO) dan memainkan peran penting dalam signal seluler, tonus vaskuler, tekanan darah, sekresi hormon insulin, tonus saluran respirasi, angiogenesis dan peristaltik usus. Mt1 berperan penting untuk memproteksi sel terhadap serangan stres oksidatif tubuh, karena itu elektroakupunktur efektif menurunkan kolesterol dn trigliserida.

Akupunktur dikombinasi diet berserat tinggi berpengaruh terhadap perbaikn lemak darah, yaitu menurunkan nilai kolesterol total, kolesterol LDL, dan trigliserida, serta menaiknna kolesterol HDL pada wanita hiperlipidemia di Posyandu lansia Mojosongo, Jebres, Kota Surkarta.

\section{DAFTAR RUJUKAN}

Albert Okorocha.

(2015).

Hyperlipidemia: Etiologi and possible control. Article in IOSR Journal of Dental and Medical Sciences· November 2015

Arikunto, Suharsimi. Prosedur Penelitian Suatu Pendekatan Praktek. Edisi V. Rineka Cipta. Jakarta. 2002.

Arlena Harmon, 2011. Hyperlipidemia. Spring.

Chen, R., Chen, M., Su, T., Zhou, M., Sun, J., Xiong, J., ... Zhang, B. (2014). A 3-Arm, Randomized, Controlled Trial of Heat-Sensitive Moxibustion Therapy to Determine Superior Effect among Patients with Lumbar Disc Herniation, 2014. doi:10.1155/2014/154941

Diane Joswick, (2012). Acupuncture for Cholesterol Management

Dharma,K.K.(2011). Metodologi Penelitian Keperawatan : Panduan melaksanakan dan menerapkan hasil penelitian. Jakarta : TIM

Hofstede, S. N., Marang-van de Mheen, P. J., Wentink, M. M., Stiggelbout, A. M., VleggeertLankamp, C. L. a, Vliet Vlieland, T. P. M., \& van Bodegom-Vos, L. (2013). Barriers and facilitators to implement shared decision making in multidisciplinary sciatica care: a qualitative study. Implementation Science: IS, 8(1), 95. doi:10.1186/1748-5908-8-95. 
Hofstede, S. N., Marang-van de Mheen, P. J., Wentink, M. M., Stiggelbout, A. M., VleggeertLankamp, C. L. a, Vliet Vlieland, T. P. M., \& van Bodegom-Vos, L. (2013). Barriers and facilitators to implement shared decision making in multidisciplinary sciatica care: a qualitative study. Implementation Science: IS, 8(1), 95. doi:10.1186/1748-5908-8-95.

Ishwarlal Jialal, Sridevi Devaraj, Laboratory Investigation Of Dyslipidemia. Boratory Medicine Volume 29, Number 7 July 1998 On 06 February 2018

Kylie A. O'Brien Review Article Alternative Perspectives: How Chinese Medicine Understands Hypercholesterolemia.

Volume 2010, Article ID 723289 , 9 pages http://dx.doi.org/10/1155/2010/72 3289

LIANG Feng-ying, Effects of Acupuncture on Hyperlipidemia and Hyperviscosity in Old People. Journal of Acpuncture and Tuina Science, Feb. 2005. Vol.3, No.1

Mark T. Mc Auley, Kathleen M. Mooney: Computationally Modeling Lipid Metabolism and Aging: A Mini-review. Computational and Structural Biotechnology Journal 13 (2015) 38-46 journal homepage: www.elsevier.com/locate/csbj.

Niharika Verma, Review Article Introduction To Hyperlipidemia And Its Treatment: A Review International Journal of Current Pharmaceutical Research ISSN0975-7066 Vol 9, Issue 1, 2017
Nursalam. Konsep dan Penerapan Metodologi Penelitian Ilmu Keperawatan. Edisi I. Salemba Medika. Jakarta.2003.

Rhea V. Morgan, 2011. Hyperlipidemia. by Saunders, an imprint of Elsevier Inc. All rights reserved.

Rebecca L. Remillard. 2014. Hyperlipidemia. Clinicians brief.com September 2014

Richards S et al (2015). Standards and guidelines for the interpretation of sequence variants: a joint consensus recommendation of the American College of Medical Genetics and Genomics and the Association for Molecular Pathology. Genet Med 2015 Mar 5 , in press.

Setiadi. (2013). Konsep dan praktik penulisan riset keperawatan. Yogjakarta : Graha Ilmu

Sugiyono. (2007). Statistika untuk Penelitian. Bandung : Alfabeta

Tieraona Low Dog, (2003). Management of Hyperlipidemia. Continuing Medical Education.

Douglas Laboratory. Alternative Therapies Mei/Juni 2003. Vol.9 No. 3. www. Douglaslab.com

Tian, J. Y., Q. Wang, Y. F. Chen, Y. Xiao, W. Yue, and H. X. Zhang. "Effect of electroacupuncture stimulation of" Fenglong"(ST 40) on expression of inflammatory cytokines of celiac macrophages in hyperlipidemia rats." Zhen ci yan jiu $=$ Acupuncture research/[Zhongguo yi xue ke xue yuan Yi xue qing bao yan jiu suo bian ji] 39, no. 4 (2014): 282-287.

Wang L, Zhang N, Pan H, Wang Z, Cao $Z$ (2015) A Combination of Electro-Acupuncture and Aerobic 
Exercise Improves Cardiovascular

Function in Patients with

Coronary Heart Disease. J Clin

Exp Cardiolog 6: 402.

doi:10.4172/2155-9880.1000402

Wei He, Xiao-Yu Wang, Li Zhou, ZhiMei Li, Xiang-Hong Jing, ZhongLi Lv, Yu-Feng Zhao, Hong Shi, Ling $\mathrm{Hu}$, Yang-Shuai $\mathrm{Su}$, and Bing Zhu. 2015. Transcutaneous Acupuncture Models: Human Body, Skeletonan, Skull and Acupuncture Model. Tradisional Chinese Medicine (TCM) for High Cholesterol 